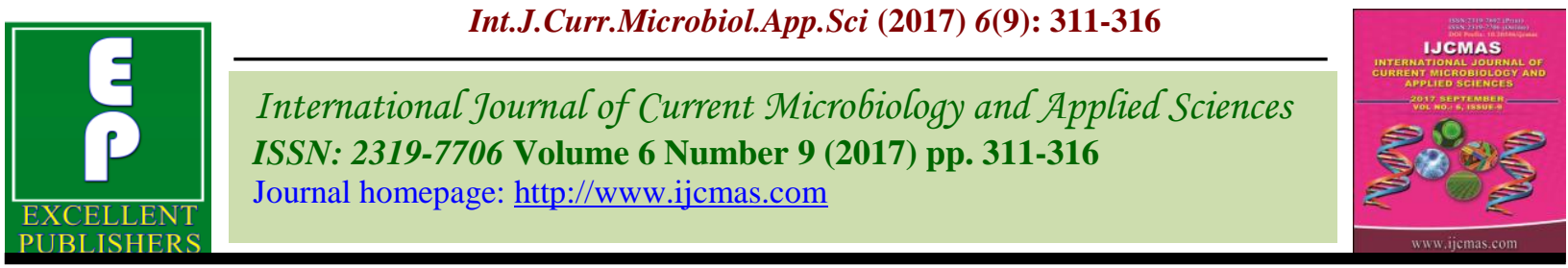

Review Article

https://doi.org/10.20546/ijcmas.2017.609.039

\title{
The Role of Horticultural Crops in Enhancing Nutrient Security
}

\author{
Rajani* and Shourabh Joshi
}

NIMS University, Rajasthan, India

*Corresponding author

\section{A B S T R A C T}

The growth of horticultural crops is economically rewarding. This sector is expected to grow and contribute to food and nutritional security, provided, the sector is nurtured with focused infrastructure development and has a conducive policy environment. Fruit and

\begin{tabular}{|l|}
\hline Key w or d s \\
Horticulture, \\
Phytochemicals, \\
Malnutrition and \\
Nutritional Security \\
\hline Article Info \\
\hline Accepted: \\
04 July 2017 \\
Available Online: \\
10 September 2017 \\
\hline \hline
\end{tabular}
vegetables are packed full of goodness and often contain a number of essential vitamins and minerals that cannot be found in other types of foods or they may contain higher levels of these nutrients than other foods. Vegetables and fruit provide a significant part of human nutrition, as they are important sources of nutrients, dietary fiber, and phytochemicals. A diet rich in vegetables and fruits can lower blood pressure, reduce risk of heart disease and stroke, prevent some types of cancer, lower risk of eye and digestive problems, and have a positive effect upon blood sugar which can help keep appetite in check. Horticultural produce with high nutritive value and is considered to be a vital component of a diversified and nutritious diet. They become more important those countries where highly prevalent malnutrition makes nutritional security an important public health concern. Horticultural interventions to enhance food safety at farm level combined with extensive nutrition and food safety education can offer a long term food based strategy to control and eliminate micronutrient malnutrition in the resource poor people. Horticultural production is relatively easy for unskilled people and it can play an important role in poverty alleviation programs and food security initiatives by providing work and income opportunities.

\section{Introduction}

The term 'horticulture' is derived from the Latin terms 'hortus' (garden) and 'cultura' (cultivation), which means garden cultivation. Horticulture is the science and art of gardening which is associated with the cultivation of fruits, vegetables, flowers, spices, ornamental plants, plantation crops, tuber crops, medicinal and aromatic plants. Horticultural crops are some of the main components of a healthy diet. The constituents obtained by the human body from fruits and vegetables include water, carbohydrates, fats, proteins, fiber, minerals, organic acids, pigments, vitamins and antioxidants, among others.

Fruits and vegetables, especially, are a good source of fiber, selected minerals, vitamins and antioxidants. Most fruits and vegetables are available almost year-round in a wide variety and they not only taste good, but they also have favorable attributes of texture, color, flavor and ease of use.

They can be fresh, cooked, hot or cold, canned, pickled, frozen or dried. 
What is food and nutrition security?

The FAO Committee on World Food Security has combined different elements and states

'Food and nutrition security exists when all people at all times have physical, social and economic access to food, which is safe and consumed in sufficient quantity and quality to meet their dietary needs and food preferences, and is supported by an environment of adequate sanitation, health services and care, allowing for a healthy and active life'.

\section{Malnutrition: The largest threat to global health}

Over 900 million people in the world are undernourished

Malnutrition responsible for 3.5million deaths each year

Malnutrition suppresses the immune system and contributes to half of all childhood deaths 250,000 to 500,000 children lose their sight every year due to Vitamin A deficiency

Over half the world's population suffers from iron deficiency, which reduces their productivity and school performance.

Vitamin C deficiency compromises immunity and results in poor wound healing.

\section{Fruits and vegetables: Easiest solution}

Fruits and vegetables improve nutrient absorption in a diet high in phytate (whole grains, seeds, pulses)

Green leafy vegetables-Fe, Vitamin A

More available Fe than legumes
Tree nuts, Portulaca-Essential fatty acids (Omega 3)

Mango, Pumpkin, Carrot, Orange-fleshed sweet potato - Vitamin A, Vitamin C

1/2 cup pumpkin, 2/3 a carrot, 1 mango supplies RDA of Vitamin A and Vitamin C

Citrus, guava, broccoli, peppers, potatoVitamin C

Food products better accepted and possibly more sustainable than vitamin supplements or pharmaceuticals for some populations

\section{The importance of nutrient content}

From human nutrition point of view horticulture is most important to our daily living. Many of the horticulture crops and their products find place in our meals and diet. Human body requires vitamins, minerals, proteins, energy etc. for its health.

All these are supplied by horticultural crops. Fruits and vegetables are the chief sources of vitamins, minerals, carbohydrates, fats, proteins etc. Fruits and vegetables are recognized as protective foods as they are necessary for the maintenance of human health.

\section{Enzymes and pigments}

Fruits and vegetables apart from being rich in vitamin and minerals are rich in colour imparting pigments and enzymes.

The chief pigments of fruits and vegetables are carotenoids, chlorophyll and anthocyanin.

Fruits and vegetables apart from being rich in vitamin and minerals are rich in colour imparting pigments and enzymes. 
Fruits and vegetables also contain certain specialized chemicals called enzymes. These are important in fruits because of the chemical changes that they initiate.

Ficin in figs and papain in papaya are the major proteolytic enzymes. These enzymes can react with proteins of the human skin and cause dermatitis.
Phenoloxidases in potatoes, apples, pears, grapes, strawberries, and figs are responsible for the discoloration of cut surfaces when exposed to air.

Other enzymes responsible for color changes in fruits and vegetables are chlorophyllases, anthocyanases and peroxidase.

\section{The four dimensions of food security}

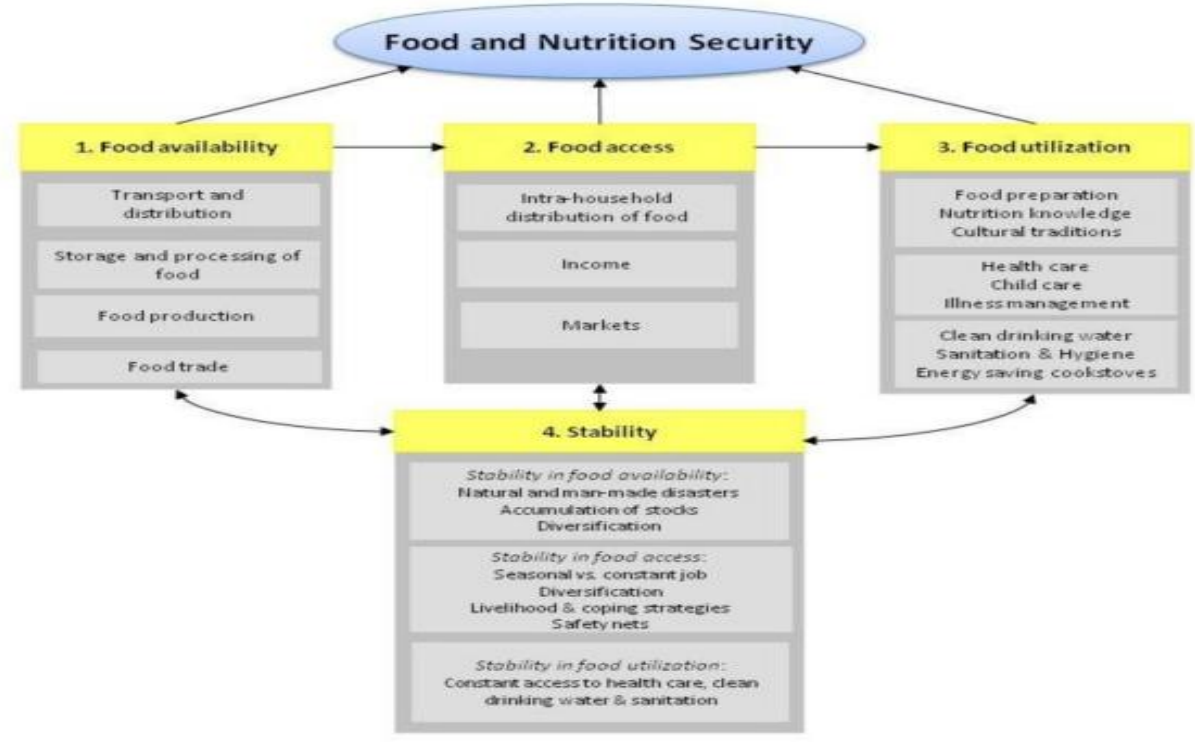

An integrated food and nutrition system
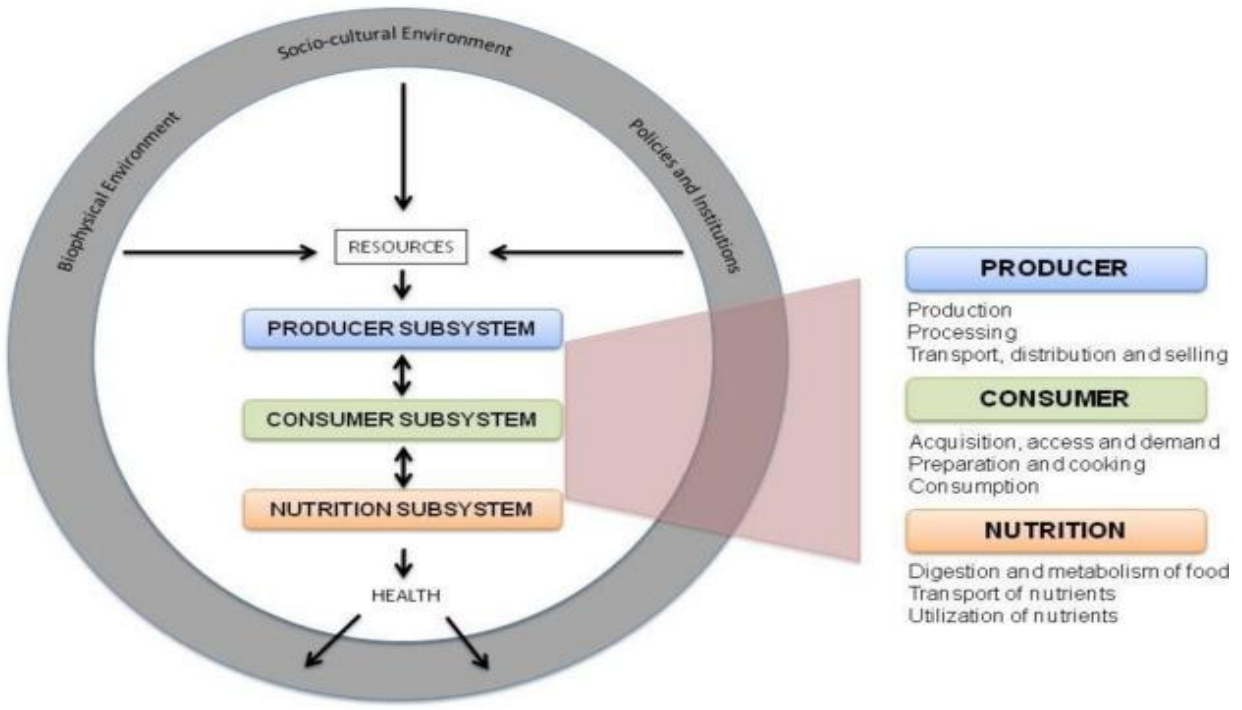
Nutritional quality of some horticultural crops

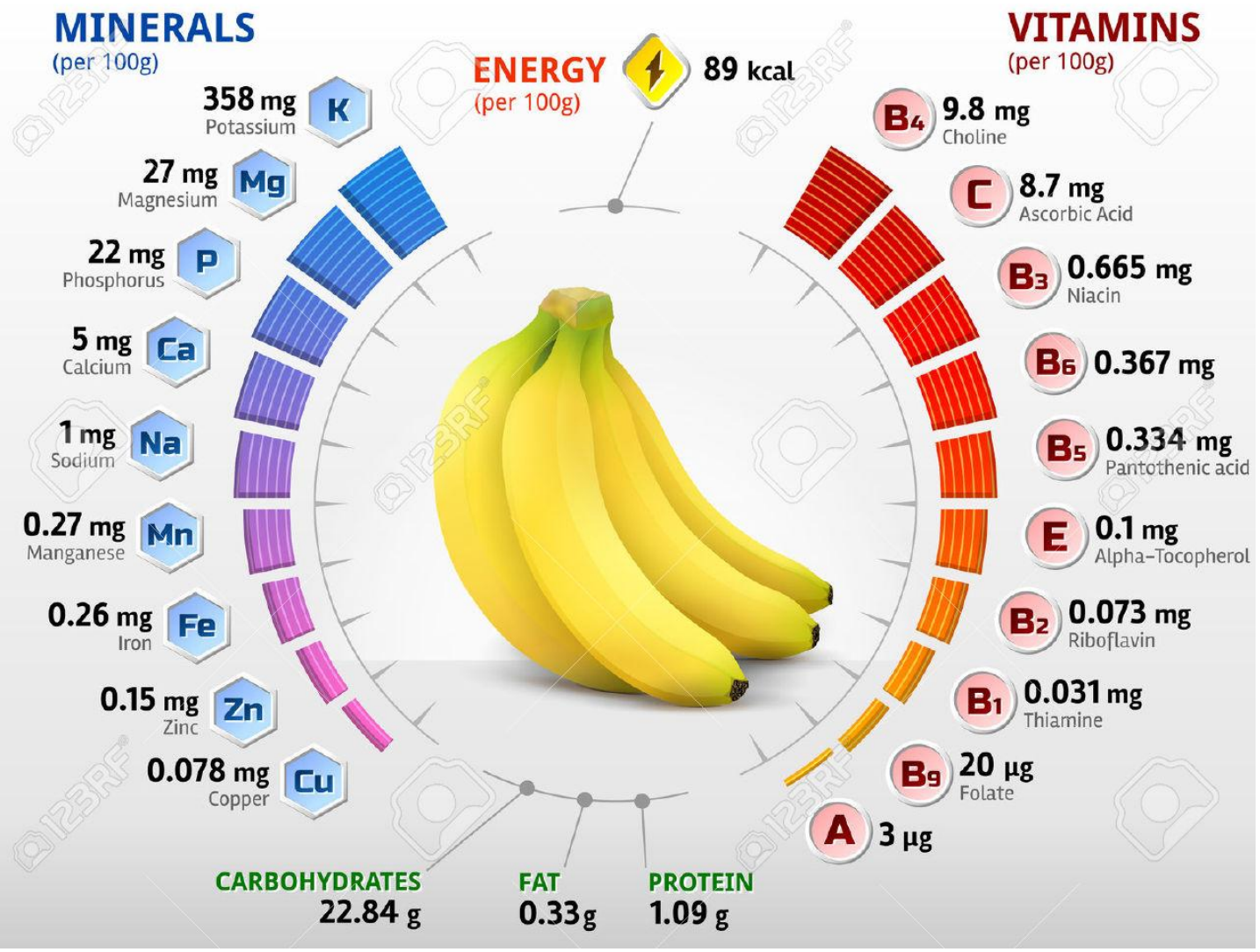

Nutritional Value of Potato
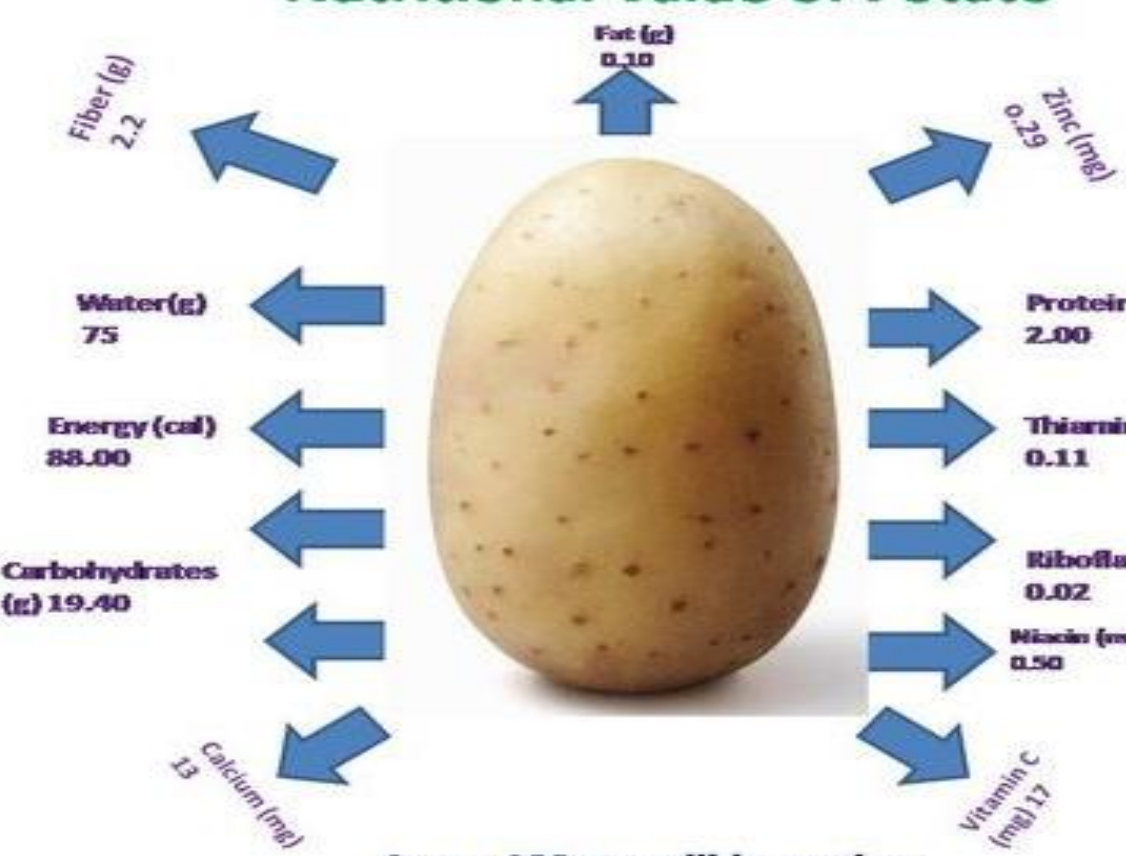

In per $100 \mathrm{gm}$ edible portion

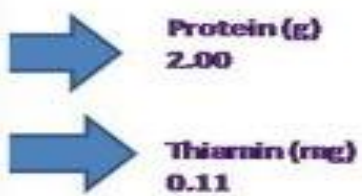

0.11

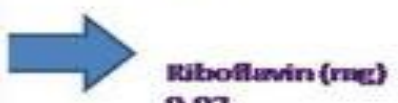

0.02

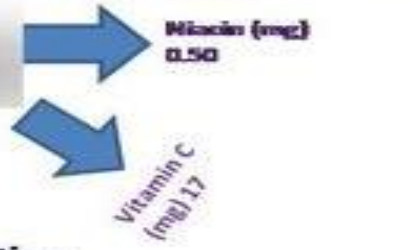




\section{Compositional Features of Fruits and Vegetables}

\begin{tabular}{|c|c|c|c|c|}
\hline & Fruits & Legumes & Leafy vegetables & Roots and tubers \\
\hline & \multicolumn{4}{|c|}{ g/100 g edible matter } \\
\hline Water & $61.0-89.1$ & $74.6-80.3$ & $84.3-94.7$ & $62.3-94.6$ \\
\hline Protein & $0.5-1.1$ & $5.7-6.9$ & $0.2-3.9$ & $0.1-4.9$ \\
\hline Fat & Trace-4.4 & $1.0-15$ & $0.2-1.4$ & $0.1-0.4$ \\
\hline Sugar & $4.4-34.8$ & $1.8-3.2$ & $1.5-4.9$ & $0.5-9.5$ \\
\hline Starch & Trace -3.0 & $5.4-8.1$ & $0.1-0.8$ & $11.8-31.4$ \\
\hline Dietary fiber & $2.0-14.8$ & $4.5-4.7$ & $1.2-4.0$ & $1.1-9.5$ \\
\hline Energy, kcal & $90-646$ & $247-348$ & $65-177$ & $297-525$ \\
\hline Micronutrient & $\begin{array}{l}\text { Vitamin } \mathrm{C}, \mathrm{K}, \\
\mathrm{Mg} \text {, carotenoids }\end{array}$ & $\begin{array}{l}\text { B vitamins, vitamin } \\
\mathrm{C}, \mathrm{K}, \mathrm{Mg}, \mathrm{P}, \mathrm{Fe}\end{array}$ & $\begin{array}{l}\text { Vitamin } \mathrm{C} \text {, folate, } \\
\text { carotenoids, } \mathrm{Ca}, \mathrm{Fe}\end{array}$ & $\begin{array}{l}\text { Vitamin E, carotenoids, } \\
\mathrm{Fe}, \mathrm{K}, \mathrm{Ca}\end{array}$ \\
\hline $\begin{array}{l}\text { Toxic } \\
\text { constituents }\end{array}$ & $\begin{array}{l}\text { Cyanogenetic } \\
\text { glycosides in } \\
\text { seeds }\end{array}$ & $\begin{array}{l}\text { Hemoagglutonins, } \\
\text { lectins, trypsin } \\
\text { inhibitors }\end{array}$ & Glucosinolates & Glycoalkaloids \\
\hline
\end{tabular}

Lipoxygenase and lipase are the enzymes linked with off-flavour in frozen peas and beans.

Citrus fruits and tomatoes are rich in pectin esterase, and pears and tomatoes in polygalacturonase, both being pectolytic enzymes responsible for softening of fruit texture during ripening.

\section{Systems approach to address nutrient deficiencies}

Production of leafy greens, mango, sweet potato, carrots, tree nuts, and portulaca for diet diversification in combination with animal products.

Link production systems with local processing of improved complementary foods for infants and young children, including lipid-based supplements

Develop a processing industry with woman's groups to increase year-round availability

Microfinance

Appropriate technologies
Concentrated solar drying

Powder production and packaging

Storage systems for dried products using Zeolite (drying material)

Puree production and packaging

Education of women

Effects of malnutrition

Nutritional value of horticulture crop additives

Methods of utilization

Methods of storage/processing

The growth of horticultural crops is economically rewarding. This sector is expected to grow and contribute to food and nutritional security, provided, the sector is nurtured with focused infrastructure development and has a conducive policy environment. Horticultural interventions to enhance food safety at farm level combined with extensive nutrition and food safety 
education can offer a long term food based strategy to control and eliminate micronutrient malnutrition in the resource poor people. Horticultural production is relatively easy for unskilled people and it can play an important role in poverty alleviation programs and food security initiatives by providing work and income opportunities. Regular eating of a vegetable rich diet has positive effects on health since phytonutriceuticals of vegetables can provide safety to the human body from several types of chronic diseases. The process by which vegetables decrease risk of disease is complex and largely unknown. Various elements of the whole food are likely to contribute to the overall health benefit. Various phytonutriceuticals having antioxidant properties may work directly by quenching free radicals or indirectly by participating in cell signaling pathways sensitive to redox balance (Padhy and Behera, 2015). Although research evidence supports the collaboration between fruit and vegetable consumption and decreased incidence and mortality of chronic diseases such as obesity, different cancers and cardiovascular diseases, disagreements still exist in the science community with reference to their association, therefore further studies with large population groups over long periods of time is recommended.

\section{References}

Padhy, C., and Behera, S. 2015. Role of Horticulture in Human Nutrition: An Analytical Review. International Journal of Engineering Technology, Management and Applied Sciences. 3(6). Pp. 167-176.

Slavin, J.L., and Lloyd, B. 2016. Health Benefits of Fruits and Vegetables. Advances in Nutrition- An International Review Journal. Pp 506-513 http://hortcrsp.ucdavis.edu

\section{How to cite this article:}

Rajani and Shourabh Joshi. 2017. The Role of Horticultural Crops in Enhancing Nutrient Security. Int.J.Curr.Microbiol.App.Sci. 6(9): 311-316. doi: https://doi.org/10.20546/ijcmas.2017.609.039 